УДК $821.112 .2-145.03=161.2=111$

DOI https://doi.org/10.26661/2414-1135-2021-84-26

\title{
ОБРАЗ ФАУСТА: ПРАГНЕННЯ ДО ЗНАНЬ І ТЯГАР МУДРОСТІ (НА МАТЕРІАЛІ ТРАГЕДІЇ Й. В. ГЕТЕ «ФАУСТ» ТА ЇЇ УКРАЇНСЬКИХ І АНГЛОМОВНИХ ПЕРЕКЛАДІВ)
}

\author{
Наняк Ю. О. \\ кандидат філологічних наук, \\ доиент кафедри перекладознавства і контрастивної лінгвістики \\ імені Григорія Кочура \\ Львівський національний університет імені Івана Франка \\ вул. Університетська, 1, Львів, Україна \\ orcid.org/0000-0003-4398-9501 \\ yuliya.nanyak@lnu.edu.ua
}

\section{Ключові слова:}

перекладознавство, переклад, мовна особистість, Гете, $\Phi$ aycm.
"Faust" Й.В. Гете - видатне явище світової культури й водночас глибоко національний твір. Всеохопність поетичного задуму Й.В. Гете виявляється в змалюванні головного героя, який мучиться розривом між мрією та дійсністю. Й.В. Гете писав «Фауста» все своє життя, вклавши в трагедію те, чим жив сам, усі свої враження, роздуми, пізнання. У статті подано стислий перекладознавчий аналіз мовної особистості Фауста 3 однойменної трагедії Й.В. Гете та їі українських (І. Франка, Д. Загула, М. Улезка й М. Лукаша) та англомовних (британських - А. Свонвік і Дж. Пріста - і американських: Б. Тейлора, Ч. Брукса й Е. Кляйна) перекладів. Запропонованопідхіддо аналізуіндивідуалізованого мовлення персонажа через когнітивний і мотиваційний рівні мовної особистості (за Ю. Карауловим), зокрема, на когнітивному рівні розглянуто ключові когнітивні установки й метафору, притаманну персонажу Фауста. Завдяки аналізу мовлення персонажа й шляхів вираження емоцій в оригіналі й перекладах можемо зробити висновки про успішність відтворення аналізованої мовної особистості. Усі перекладачі іноді замінювали усвідомлення Фаустом себе або інших конкретних та абстрактних людей виразами, де присутні поняття «дух», «душа» й «серце», використовуючи слова "spirit" i «дух» набагато частіше, ніж слово "Geist", вжите в оригіналі. Отже, можна припустити, що образ Фауста також змінюється в перекладах: він стає більш емоційним і вірить у духовність усього, що його оточує. У перекладі I. Франка можна помітити разючу відмінність, оскільки слово «душа» вживається лише 5 разів, тобто на відміну від усіх інших аналізованих перекладів навіть менше, ніж в оригіналі. Фауст у перекладі І. Франка більше наголошує на поняттях «дух» і «серце» як двох принципах, які у своєму дуалізмі провокують персонажа шукати сенс життя. Аналіз образу Фауста проведено на основі всієї його мовної партії в першій частині трагедії Й.В. Гете, що складає 221 висловлювання (репліки в діалогах і монологи). Усі вони певною мірою відтворені в аналізованих українських та англомовних перекладах, тобто загальний матеріал для аналізу налічує 2210 уривків різної довжини. 


\title{
IMAGE OF FAUST: THE PURSUIT OF KNOWLEDGE AND THE BURDEN OF WISDOM (BASED ON THE TRAGEDY BY J. W. GOETHE "FAUST" AND ITS ANGLOPHONE AND UKRAINIAN TRANSLATIONS)
}

\author{
Naniak Yu. O. \\ Candidate of Philological Sciences, \\ Associate Professor at the Department of Hryhoriy Kochur Translation Studies \\ and Contrastive Linguistics \\ Ivan Franko National University in Lviv \\ Universytetska str., 1, Lviv, Ukraine \\ orcid.org/0000-0003-4398-9501 \\ yuliya.nanyak@lnu.edu.ua
}

Key words: Translation Studies, translation, language personality, Goethe, Faust.

\begin{abstract}
J.W. Goethe's tragedy "Faust" is an outstanding phenomenon of the world culture and at the same time a national work. The comprehensiveness of Goethe's poetic idea is manifested in the depiction of the protagonist, who suffers from the gap between dream and reality. J.W. Goethe was writing "Faust" during all his life, investing everything he cared for, all his impressions, thoughts and knowledge into the tragedy. The article presents a brief translation studies analysis of the language personality of Faust from the tragedy of J.W. Goethe and its Ukrainian and Anglophone translations. The approach to character analysis through the cognitive and motivational levels of the language personality is suggested, in particular, at the cognitive level, key cognitive guidelines and the cognitive metaphor inherent in the image of Faust are considered. By analysing the character's speech and ways of expressing emotion in the original and translations, we can come to the conclusion that the analysed language personality has been successfully reproduced. All translators have sometimes replaced Faust's awareness of himself or of other specific and abstract people with expressions where the concepts of spirit, soul and heart are present, using the words "spirit" and «дух» much more often than the word "Geist" was used in the original. Thus, we can assume that the image of Faust is also changing in translations: he becomes more emotional and believes in the spirituality of everything that surrounds him. In the translation by I. Franko a striking difference can be observed, because the word «душа» is used only 5 times, that is, unlike all other translations that were analysed, even less than in the original. Faust by I. Franko emphasizes more on «дух» and «серце» as two principles that in their dualism provoke this character to search for the meaning of life. The analysis of Faust's image was conducted on the basis of his entire language party in the first part, which consists of 221 utterances (replicas in dialogues and monologues), all of them to some extent were reproduced in the analysed Ukrainian and Anglophone translations (that is, the total material for analysis consists of 2210 passages of different lengths).
\end{abstract}

Мета: встановлення особливостей індивідуалізації мовленнєвої поведінки Фауста з однойменної трагедії Й.В. Гете й окреслення труднощів, які вони становлять для перекладу, а також з'ясування причин модифікацій і наслідків таких змін.

Завдання: схарактеризувати когнітивний i прагматичний рівні мовної особистості Фауста в першій частині трагедії Й.В. Гете "Faust" і встановити, яких змін і трансформацій зазнав персонаж в українських та англомовних перекладах, а також співвіднесеність таких змін залежно від рівня мовної особистості й впливу на цільового читача.

Об’єктом дослідження є індивідуалізоване мовлення Фауста з однойменної трагедії Й.В. Гете. Предметом дослідження $є$ засоби й способи відтворення індивідуалізованого мовлення Фауста 3 трагедії Й. В. Гете "Faust” цільовими мовами (англійською та українською).

Проблема мовної особистості знаходиться в центрі сучасної антропоцентричної лінгвістики, а започаткував дослідження явища Ю. Караулов 
[8; 12 та інші]. Мовна особистість виражається в мові й через мову; вона насичує додатковим смислом і поглиблює поняття «особистість» [8, с. 38] через мовні здібності й комунікативну компетенцію індивіда [12, с. 223].

Когнітивний рівень мовної особистості характеризує «властиву їй картину світу й утілений в iii тезаурусі» [8, с. 87]. Передбачається існування певної домінанти, яка визначається національною культурою, традиціями й прийнятою в суспільстві ідеологією. Таким чином, перший рівень вивчення мовної особистості передбачає виділення в іiї картині світу варіативної частини на основі знання їі ядерної складової частини.

Мотиваційний рівень охоплює «комунікативно-діяльнісні потреби особистості», співвідносячи «мотиви, які нею керують, установки <..> мети, «інтенціональності» особистості з мовною поведінкою та іiі змістом» $[8$, с. 88]. «Інваріантом тут треба вважати уявлення про сенс буття, мету життя людства й людини як виду гомо сапієнс, тоді як змінну частину складають індивідуальні мотиви й цілі» [8, с. 38]. Це другий значущий рівень 3 інтелектуального (когнітивного) погляду. Зрозуміло, що поділ на рівні досить умовний, адже жоден із них не може існувати окремо.

У Страсбурзі на початку 70-х pp. 18 ст. Й.В. Гете створив перший варіант великого твору - «Пра-Фауст» (Uhrfaust). Його герой-молодий чоловік, який відкидає схоластичне знання та рветься назустріч життю з усіма його радощами й бідами; до такого його спонукає сама природа, «Дух Землі». Центр «Пра-Фауста» - трагедія природного почуття, подібна до тієї, про яку Гете розповів у «Стражданнях юного Вертера». Мотиви «Пра-Фауста» збереглися в першій частині «Фауста», задум якого, однак, у процесі створення істотно збагатився. Герой поеми ввібрав у себе риси й гордого богоборця Прометея, і волелюбного лицаря Геца, i «титана почуття» Вертера. Провідним мотивом «Фауста» стали невтомні пошуки героя (вже не юнака, як у «Пра-Фаусті», а старця), постійна незадоволеність досягнутим, непереборне занепокоєння [9, с. 17].

Сам Й.В. Гете в розмовах із П. Екерманом так характеризував свого героя: «Характер Фауста на тій ступені, на яку підняв його 3 народної казки сучасний світогляд, - це характер людини, яка нетерпляче б'ється в рамках земного буття та вважає вище знання, земні блага й насолоди недостатніми для задоволення своїх прагнень» [13].

Фауст прагне такого існування, за якого воєдино зійдуться мрія та реальність, небесне й земне. Так само як вони сходяться в ньому самому: прагнення кращого життя для людства, роздумування над вічними філософськими питаннями й цілком земні пристрасті й вади, які йому демонструє Мефістофель.

Звичайно, образ Фауста є типізацією; цікавою $\epsilon$ семантика слова der Faust, що означає «кулак». Очевидно, що Й.В. Гете іiі не використовував. Також у німецькій мові присутні ідіоматичні вислови із цим словом, більшість яких містять такі поняття, як гнів, страх і ризик.

Репліка, де Фауст звертається до Мефістофеля, щоб той якнайшвидше знайшов новий убір для Гретхен, бо попередній iii мати віддала священникові, $є$ ілюстративною для аналізу відтворення мікрокогнітивних категорій:

Sei, Teufel, doch nur nicht wie Brei

Und schaff einen neuen Schmuck herbei! [15].

No milk-and-water devil be, / And bring fresh jewels instantly! [17, c. 117].

Не будь-бо, чорте, як те тісто, / І швидко стрій новий дістань! [2, с. 279].

Don't be a devil soft as pap, / And fetch me some new jewels, old chap! [18, c. 67].

Don't be a Devil stiff as paste, / But get fresh jewels to her taste! [20, c. 125].

Будь чорт як чорт, - не розмазня, - / I скарб новий придбай ще цього дня! [4, с. 88].

Будь чортом, а не киселем сиди, / Та другий вбір тягни сюди! [3, с. 187].

Devil, don't be like mush and move so slow. / Fetch some new ornaments- up, now, and run! [19].

Ти ж не макуха - чортом будь, / Таки убір їй роздобудь! [5, с. 122].

Don't be a devil made of clay, / Get her fresh jewels straight away! [16, c. 118].

Як бачимо, жоден із перекладачів не повторився у своєму виборі варіанту перекладу. Фауст порівнює Мефістофеля 3 кашею i, хоча нам не вдалося знайти таке фіксоване порівняння в німецькій мові, та порівняння все ж зрозуміле. А. Свонвік перекладає як "milk-and-water", що означає безхарактерний [1, с. 673], тобто змінює трішки образність, зберігаючи головне значення. I. Франко кардинально змінюе образ, порівнюючи Мефістофеля 3 тістом. Такий варіант також, без сумніву, вдалий, адже в українській мові існує вислів «3 м'якого тіста»- про слабовільну, нестійку людину, про людину без твердих переконань і поглядів [11, т. 10, с. 149], тобто конотації збережено. Порівняння з тістом зустрічається в перекладі Б. Тейлора, адже "stiff paste" означає густе, негнучке тісто. Ч.Т. Брукс зберігає порівняння з кашею, Д. Загул повністю зберігає образність, адже «розмазня» означає і рідку кашу, і нерішучу, слабохарактерну людину [11, т. 8, с. 734]. Дж. Пріст також відтворює порівняння 3 кашею та трішки змінює конотації, бо "mush" - це також сентиментальні дурниці [21, с. 939]. М. Лукаш частково змінює образність та, як і в більшості 
випадків, знаходить найоригінальніший варіант, який повністю підходить, бо лексема «макуха» позначає вайлувату, в'ялу, безхарактерну людину [21, т. 4, с. 604].

Можна виділити такі ключові когнітивні установки Фауста:

1. Розчарування чи навіть відчай, що доступних знань недостатньо для того, щоб осягнути світ.

2. Прагнення до мудрості.

3. Ідіосинкризація обмежених людей і прагнення до простоти.

4. Фауст також постає яскравим прикладом дуалізму людської природи.

Розглянемо, як перші дві установки трансформуються в перекладах.

FAUST. Ich fühls, vergebens hab ich alle Schätze

Des Menschengeists auf mich herbeigerafft,

Und wenn ich mich am Ende niedersetze,

Quillt innerlich doch keine neue Kraft;

Ich bin nicht um ein Haar breit höher,

Bin dem Unendlichen nicht näher [15, c. 182].

У цитованому фрагменті вербалізується перша когнітивна установка, а образ Фауста трансформується через зміни, які запровадили перекладачі. Найточніше відтворив цей фрагмент I. Франко ( $Я$ чую, дарма я згромадив / Всі скарби людського знання, / А як вкіниі отак я сяду - / 3 нутра ми сила не плине нова; / Я й крихти не зробився вищий, / I к безконечному не ближчий [2, с. 237]). Проте й тут $є$ певна неточність: замість скарбів людського розуму - скарби людського знання, тобто ототожнюються два поняття. Подібним є і варіант М. Лукаша: «Не радує мене тих знань скарбниця, / Що я збирав на протязі років...» [5, c. 71]. Та найближче до оригіналу таке визначення слова «знання»: пізнання дійсності в окремих іiї проявах і в цілому [11, т. 3, с. 641], коли ж «розум» - здатність людини мислити, відбивати й пізнавати об'єктивну дійсність (прикл. Розум скарб людини) [11, т. 8, с. 838].

М. Улезко й Е. Кляйн використали метонімічну трансформацію, яка зумовлена калькуванням (тобто вони актуалізували значення слів, 3 яких складається "Menschengeists") «Даремно-ж згріб собі я, чую, / Людського духа всі добра» та "All the treasures of the human spirit / I feel that I've expended, uselessly", i, таким чином, Фауст нагромаджує скарби людського духу. 3 англомовних перекладів найближче до оригіналу уривок вдалося відтворити американцю Б. Тейлору: "I feel, indeed, that I have made the treasure / Of human thought and knowledge mine, in vain" [20, c. 72].

А. Свонвік підкреслює те, що знання здобуті важкою працею "from studious toil I rest". Т. Брукс та Е. Кляйн включають вставки "let me not deny it" та “as you see”, що додає герою непевності й відчаю, він начебто когось переконує. Д. Загул додає до відчаю ще й драматизм: «Як тільки з горя я заламлю руки, / В моїй душі ніяких сил нема», пропускаючи слово "пеие", тобто нема не просто нових сил, а взагалі ніяких, і через це Фауст тут постає ще й виснаженим. Також цікаве ставлення перекладачів до слова «іnnerlich»: А. Свонвік перекладає як "within my breast", а Дж. Пріст - "within my brain", Б. Тейлор - "in my brain” [20, с. 72], Д. Загул - «В мойй душі ніяких сил нема», М. Улезко - «із нутра», І. Франко - «з нутра». Тож розташування сили, яке в оригіналі означене без деталізації, тобто всередині, без точного місця, у перекладах змінюється, що також впливає на мовленнєвий образ персонажа. Варіант А. Свонвік можна сприйняти як звернення до кордоцентричної концепції мислення, адже нова сила повинна була б виникнути в серці. На противагу його варіанту Ч. Брукс і Б. Тейлор знаходять джерело сили в розумі. Цікаві варіанти I. Франка й М. Улезка. Вони використали слово «нутро», що означає середина, нутрощі, - лише таке значення подано в словнику Б. Грінченка. У Словнику української мови вже 3'являється значення, яке відповідніше для адекватного відтворення оригіналу: «внутрішня суть кого-, чого-небудь. Внутрішній психічний світ людини; душа» [11, т. 5, с. 457]. Британець Е. Кляйн переклав фрагмент нейтрально: «іn те». У перекладі М. Лукаша бачимо реметафоризацію: "Quillt innerlich doch keine nеме Kraft" - «То духом я ні крихти не змічнів» і додає «Я ніби й ріс» [5, с. 71], що вказує на те, що герой страждає не лише від розчарування та відчаю, але й від втрати ілюзій.

Wo faß ich dich, unendliche Natur?

Euch Brüste, wo? Ihr Quellen alles Lebens,

An denen Himmel und Erde hängt,

Dahin die welke Brust sich drängt-

Ihr quellt, ihr tränkt, und schmacht ich so vergebens? [15]

В уривку - часткова реметафоризація Фаустом природи як джерела мудрості. Освальд Бурггард гостро критикував уривок у перекладі М. Улезка: «Натуро безконечна! як-же тебе взять? / Життя всього кринице - де ви тиї груди, / Де небо $i$ земля висить?» [3, с. 63] за надмірний буквалізм: «Що-ж можна закинути перекладачеві? Та нічого. Він перекладав буквально < ..> По-українському не кажуть, що дитина висить на матерніх грудях, а що вона припадає до грудей. Фавст шукає тих таємних джерел життя, що до них, мов до грудей, земля та небо припадають, вбираючи в себе творчу силу, - таке значення мають ці рядки» [7, с. 108-109].

У перекладі Д. Загула зникає метафора грудей, натомість з'являються сили, «сили ті, щзо держать все - $i$ всюди». I. Франко поглиблює 
метафору звертанням «предвічна мати» (Така метафоризація притаманна перекладачеві, згадаймо вірш «Земле, моя всеплодющая мати, / Сили, щзо в твоїй живе глубині, / Краплю, щэоб в бою сильніше стояти, / Дай $і$ мені!). У всіх інших аналізованих перекладах метафору грудей збережено: в А. Свонвік: "Where shall I grasp thee, infinite nature, where? / Ye breasts, ye fountains of all life, whereon / Hang heaven and earth"; у Б. Тейлора: "Thee, boundless Nature, how make thee my own? / Where you, ye beasts? Founts of all Being, shining, / Whereon hang Heaven's and Earth's desire" [20, с. 20]; у Ч. Пріста: "Where shall I, endless Nature, seize on thee? / Thy breasts are- where? Ye, of all life the spring, / To whom both Earth and Heaven cling". T. Брукс додає, що природа не лише неосяжна, але й невідома: "Nature! where find I thee, immense, unknown? / Where you, ye breasts? Ye founts all life sustaining, / On which hang heaven and earth". $\mathrm{y}$ всіх вищезгаданих англомовних перекладах збережено шанобливу множину оригіналу, навіть посилено, адже в Й.В. Гете Фауст звертається до природи спершу “dich", в однині, а потім: “Euch”, а в перекладах: “thee”, “Thy” та “уе”. Пояснити це можна часом створення перекладу, бо, коли створювалися ці переклади, така шаноблива множина вживалася часто. У Е. Кляйна: "How then can I grasp you endless Nature? / Where are your breasts that pour out Life entire, / To which the Earth and Heavens cling so" - вживаються вже стандартні й звичні для сучасного читача “уоu” та "your". Усі українські перекладачі, крім Д. Загула, звертаються до природи на «ти», проте це зовсім не означає вияву неповаги, адже «ти» «вживається в риторичному звертанні до кого-, чого-небудь» [11, т. 10 , c. 107].

M. Лукаш реметафоризував риторичне питання: «Невже ж ти болю в сериі не загоӥи, / Жаги палкої в нім не заспокоїи». Хоч дослівно варіант далекий від оригіналу, однак суть передано досить добре (груди від природи наповнюються, та страждання даремні). У Б. Тейлора переклад дослівний: "Whereto our withered hearts aspire,- / Ye flow, ye feed: and am I vainly pining?" [20, с. 20], також дуже близькими до оригіналу $є$ варіанти Дж. Пріста: "Toward whom the withering breast doth strain- / Ye gush, ye suckle, and shall I pine thus in vain?" та Е. Кляйна: "Where withered hearts would drink? You flow / You nourish, yet I languish so, in vain desire”. А Свонвік двічі повторює запитання, очевидно, щоб підкреслити відчай: "Your sweet and fostering tides - where are ye where? / Ye gush, and must I languish in despair?", також в іiі перекладі епітетна конструкція "withered heart" переміщується на рядок вище й змінює суть питання "schmacht ich" (тобто мучусь перетворюється на “must I languish” (чи мушу я сумувати)). Примус бачимо й у варіанті Ч. Брукса: "Men's withered hearts their waste repair - / Ye gush, ye nurse, and I must sit complaining", та це єдина суттєва відмінність від оригіналу. У варіанті фрагменту I. Франка: «'Д котрій я тиснусь, зв'ялений пожаром? / Вона поїть $і$ живить - я прагну, смагну даром»; груди відтворено гіперонімічно, тобто «я» загалом, але не слабкий чи зів'ялий, а «зв'ялений пожаром». Очевидно, «nожар» вжито в переносному значенні: «сильне почуття, що швидко охоплює кого-небудь» $[11$, т. 6 , с. 772], а «зв'ялений» - досить вдалий відповідник, бо семантика слова зв'ялити - спричинитися до страждань, тяжких переживань [11, т. 3, с. 507]. У М. Улезка: «До вас так серие в'ялеє горить... / 3 вас ллється й поїть, - чи даремно - ж прагнуть будy?» [3, с. 63], «горить» вжито в значенні пересихає $[11$, т. 2 , с. 130$]$.

Д. Загул відтворив фрагмент досить описово: «До вас даремно рвуться хорі груди, - / Ви дасте життя... а я так довго прагну!»; також не зазначено, що прагнення даремні.

Таким чином, ми спостерігаємо в перекладах досить різне сприйняття та метафоризацію джерела мудрості природи Фаустом, що, відповідно, змінює і сам образ Фауста.

Досліджуючи індивідуальний когнітивний простір Б. Пастернака на основі його перекладу трагедіï Й.В. Гете «Faust», А. Діомідова звертає увагу на когнітивну метафору «життя - вода» у Фауста [6]. Проте для головного героя трагедії Й.В. Гете все ж притаманна векторність руху води, тому ми вважаємо, що це є частиною когнітивної метафори:

Дух, Geist $\leftrightarrow$ Tat, дія, рух, течія, лет, політ $\leftrightarrow$ Знання.

Така метафоризація відтворена у всіх перекладах однаковою мірою, що й дало можливість адекватно відбити образ.

Зокрема, слово "Geist" Фауст вживає у своїх висловлюваннях 24 рази, "Seele" - лише 9, "Herz" - 14 (+ спільнокореневе "Herzen", що означає «голубити», вжито 9 разів) і "Brust" 13. Слова, які позначають певні вияви почуттів: "liebe" - 8, "mag" - 14. Це найчастіше вживані слова (серед самостійних частин мови, окрім числівників і займенників) у всіх репліках Фауста в оригіналі трагедії. Такий лексичний вибір певним чином характеризує персонажа. Перекладачі здебільшого суттєво змінювали лексичний репертуар Фауста.

Усі без винятків перекладачі значно частіше вживали слова “spirit” " «дyx», ніж є слова “Geist” в оригіналі. Загалом усі перекладачі часом заміняли усвідомлення Фаустом себе чи інших конкретних та абстрактних людей висловами, де присутні поняття духу, душі й серця. Таким чином, можна 
припустити, що Фауст у перекладах також змінюється: набуває більшої емоційності й віри в духовність усього, що його оточує. Лише в перекладі I. Франка можна побачити разючу відмінність, адже слово «душа» вжито лише 5 разів, тобто на відміну від усіх інших перекладів, які аналізуємо, навіть менше, ніж в оригіналі. Фауст I. Франка сильніше акцентує «дуx» і «сериее» як два начала, які у своєму дуалізмі й провокують персонажа на пошуки сенсу життя. Це індивідуально-авторська особливість I. Франка, адже й в оригінальній творчості він часто використовує лексему «дух» для позначення рушійної сили людського поступу (напр., як у вірші «Вічний революціонер»).

Зміни категорій мікропрагматики під час перекладу не мали значного впливу на створення образу. Однак варто зазначити, що Фауст не використовує асемантичних мовленнєвих актів на відміну від більшості персонажів першої частини трагедії, що свідчить про те, що хоч він і стверджує в розмові з Вагнером, що слова не мають значення, та насправді ставиться дуже серйозно до сказаного, все ж на перше місце висуваючи вчинки.

Категорії макро- й мегапрагматики зазнали найменших змін з усіх аналізованих категорій. Тому можна припустити, що всі перекладачі усвідомлювали, що зміна таких категорій, як «точка зору», «емпатія», «модальність» неминуче призведе до значної зміни образу. Вияви категорії мовчання загалом неможливо змінити, коли ми говоримо про переклад, а не вільну інтерпретацію.

Категорія природності таки зазнала змін, особливо в перекладах М. Улезка й Д. Загула, та, вірогідно, це була мимовільна зміна заради збереження форми. Саме тому в їхніх перекладах Фауст хоч і критикує Вагнера за надмірне намагання використовувати завчені «мудрі» фрази, сам висловлюється таким же чином.

Подальші наукові дослідження проблем відтворення індивідуалізованого персонажного мовлення $\epsilon$ перспективним напрямом у перекладознавстві. Феномен індивідуалізації мовлення має певний потенціал як предмет дослідження в когнітивній лінгвістиці й у лінгвістичній прагматиці.

\section{ЛITЕРАТУРА}

1. Англо-український фразеологічний словник : Близько 30000 фразеологічних виразів / Уклад. К.Т. Баранцев ; відп. ред. Л.В. Кирпич. Київ : Знання, 2005. 1056 с.

2. Гете Й.В. Фавст / Перекл. І. Франко. Зібрання творів у n'ятдесяти томах / Іван Франко. Т. 13. Київ : Наук. думка, 1978. С. 174-424.

3. Гете Й.В. Фауст. Трагедія. І частина / перек. 3 нім. мови М.Т. Улезко. Київ : Держ. вид. України, 1926. 332 c.
4. Гете Й.В. Фауст. Трагедія. І частина / 3 нім. мови вірш. переклад Д.Ю. Загула ; 3 портретом Гете та 12 ілюстраціями Ліцен-Маєра. Київ - Відень : Вернигора, 1919. 136 с.

5. Гете Й.В. Фауст : трагедія / 3 нім пер. М.О. Лукаш. Київ : Вид-во Жупанського, 2013. 629 c.

6. Диомидова А.А. «Творческая личность переводчика»: когнитивная модель формализации. Kalbotyra. 2007. № 57. С. 71-81.

7. Кальниченко О.А., Полякова Ю.Ю. Українська перекладознавча думка 1920-х - початку 1930-х років : хрестоматія вибраних праць 3 перекладознавства до курсу «Історія перекладу» для студентів, що навчаються за спеціальністю «Переклад» / за ред. Л.М. Черноватого та В.I. Карабана. Вінниця : Нова Книга, 2011. 503 c.

8. Караулов Ю.Н. Русский язык и языковая личность. Москва : Наука, 1987. 264 с.

9. Лейтес Н.С. От «Фауста» до наших дней : Из истории немецкой литературы : книга для учащихся старших классов. Москва : Просвещение, 1987.223 с.

10. Словник античної мітології / Упоряд. І.Я. Козовик, О.Д. Пономарів. Тернопіль : Навчальна книга. Богдан, 2006. 312 с.

11. Словник української мови : В 11 т. / АН УРСР. Інститут мовознавства ; за ред. І.К. Білодіда. Київ : Наукова думка, 1970-1980.

12. Шахнарович А.М. Языковая личность и языковая способность. Язык-система. Язык-текст. Язык-способность : Сборник статей. Москва : Изд-во РАН. Ин-т рус. яз., 1995. С. 213-223.

13. Эккерман И.П. Разговоры с Гете в последние годы его жизни. Москва : Худож. лит., 1981. $687 \mathrm{c}$.

14. Duden Deutsches Universalwörterbuch. 5-te überarbeitete Auflage, herausgegeben von der Dudenredaktion. Dudenverlag, Mannheim - Leipzig Wien - Zürich, 2003. 1892 S.,

15. Goethe J.W. Faust. Gesamtausgabe. Leipzig : Insel-Verlag, 1969. 651 S.

16. Goethe J.W. Faust / Transl. by A.S. Kline. URL: https://www.poetryintranslation.com/PITBR/ German/Fausthome.php.

17. Goethe J.W. Faust / Transl. by A. Swanwick. London: G. Bell and Sons, Ltd, 1928. 437 p.

18. Goethe J.W. Faust / Transl. by Ch.T. Brooks. URL: http://www.gutenberg.org/etext/14460 19.

19. Goethe J.W. Faust / Transl. by G.M. Priest. URL: http://www.publicappeal.org/library/goethe/ faust/index.htm.

20. Goethe J.W. Faust : A Tragedy : Parts I and II / Transl. in original meters by B. Taylor; Introd. by A. Scenna. 2nd printing. New York: Washington Square Press, 1967. XIX, 426 p. 
21. Longman dictionary of contemporary English. Pearson Education Ltd, 2000. 1668 p.

\section{REFERENCES}

1. Anhlo-ukrainskyi frazeolohichnyi slovnyk (English-Ukrainian phraseological dictionary) (2005) K.: Znannia.

2. Goethe, J.W. (1978) Favst. Perekl. I. Franko. Ivan Franko. Zibrannia tvoriv u piatdesiaty tomakh. T. 13. K.: Nauk. dumka.

3. Goethe, J.W. (1926) Faust. Trahediia. I chastyna, perek. z nim. movy M. T. Ulezko. Derzh. vyd. Ukrainy.

4. Goethe, J.W. (1919) Faust. Tragediia. I chastyna, z nim. movy virsh. pereklad D. Zahula; KyivViden: Vernyhora.

5. Goethe, J.W. (2013) Faust: trahediia. z nim per. M. Lukash. K.: Vyd-vo Zhupanskoho.

6. Dyomydova, A. (2007) "Tvorcheskaia lychnost perevodchyka": kohnytyvnaia model formalyzatsyy (Artistic personality of the translator: cognitive model of formation). Kalbotyra. № 57. pp. 71-81.

7. Kalnychenko, O.A., Poliakova Yu.Yu. (2011) Ukrainska perekladoznavcha dumka 1920-kh pochatku 1930-kh rokiv (Ukrainian translation studies research in the 1920-ies - beginning of 1930-ies). Vinnytsia: Nova Knyha.

8. Karaulov, Yu.N. (1987) Russkyi yazyk y yazykovaia lychnost (Russian language and language personality). M. : Nauka.

9. Leites, N.S. (1987) Ot "Fausta" do nashykh dnei: iz istoryy nem. lyt. (Since Faust till our days: from the history of German literature): M. : Prosveshchenye.

10. Slovnyk antychnoi mitolohii (2006) (Dictionary of the ancient mythology). Ternopil: Navchalna knyha. Bohdan.
11. Slovnyk ukrainskoi movy: V 11 t. (Dictionary of Ukrainian language. In 11 vol.) (1970-1980). AN URSR. Instytut movoznavstva. Kyiv : Naukova dumka,

12. Shahnarovich,A.M.(1995) Jazykovaja lichnost' $i$ jazykovaja sposobnost'. Jazyk-sistema. Jazyk-tekst. Jazyk-sposobnost' (Language personality and language ability. Languagesystem. Language-text. Language-ability): Sb. statej. M. : Izd-vo RAN. In-t rus. jaz. 1995. pp. 213-223.

13. Jekkerman, I.P. (1981) Razgovory s Gete $v$ poslednie gody ego zhizni. (Talks with Goethe in the last lears of his life) M. : Hudozh. lit.

14. Duden Deutsches Universalwörterbuch. 5-te überarbeitete Auflage, herausgegeben von der Dudenredaktion, Dudenverlag, Mannheim Leipzig - Wien - Zürich. 2003.

15. Goethe, J.W. (1969) Faust. Gesamtausgabe. Leipzig: Insel-Verlag.

16. Goethe. J.W. Faust. Transl. by A.S. Kline. URL: https://www.poetryintranslation.com/PITBR/ German/Fausthome.php.

17. Goethe. J.W. (1928) Faust. Transl. by A. Swanwick. London G. Bell and Sons, Ltd.

18. Goethe. J.W. Faust. Transl. by Ch.T. Brooks URL: http://www.gutenberg.org/etext/14460.

19. Goethe. J.W. Faust. Transl. by G.M. Priest URL: http://www.publicappeal.org/library/goethe/ faust/index.htm.

20. Goethe. J.W. (1967) Faust: A Tragedy: Parts I and II. Transl. in original meters by B. Taylor; New York : Washington Square Press.

21. Longman dictionary of contemporary English (2000). Pearson Education Ltd. 